\title{
Evolution of 3'UTR-associated RNAs
}

\author{
Jan Engelhardt ${ }^{*}$, Peter F Stadler \\ From Latin American Student Council Symposium 2014 (LA-SCS 2014) \\ Belo Horizonte, Brazil. 27 October 2014
}

\section{Background}

Despite their abundance, unspliced EST data has received little attention as a source of information on non-coding RNAs. Very little is known, therefore, about the genomic distribution of unspliced non-coding transcripts and their relationship with the much better studied regularly spliced products. In particular, their evolution has remained virtually unstudied. A subclass of the unspliced EST cluster consists of so called 3'UTR-derived RNAs (uaRNAs). They can have functions in cis and trans, independent from the harboring gene. uaRNAs can be detected by combining EST data with predicted transcription start sites.

\section{Results}

We systematically study the evidence on unspliced transcripts available in EST annotation tracks for human and mouse, comprising 104,980 and 66,109 unspliced EST clusters, respectively. $15-20 \backslash \%$ of the unspliced EST cluster are conserved between human and mouse. More than 7,000 human and 6,000 mouse unspliced EST cluster overlap the 3'UTR of a RefSeq gene or are located within $5 \mathrm{~kb}$ downstream of the 3' end. Using TSS predicted by chromatin data we identify a total of 1,547 bona fide uaRNA candidates in human. Integrating only the public available CAGE data by the FANTOM5 consortium we predict a total of 1,891 uaRNA candidates in human and 2,477 candidates in mouse.

We also give a first glimpse on the sequence and structure conservation of these uaRNA candidates.

\section{Conclusions}

Expressed sequence tag data combined with experimentally predicted promoter data, e.g. CAGE, is a powerful tool to identify candidate uaRNAs. This combination of data sets could also be applied to non-model organisms

\footnotetext{
* Correspondence: jane@bioinf.uni-leipzig.de

Bioinformatics Group, Department of Computer Science, University of
} Leipzig, Leipzig, Germany

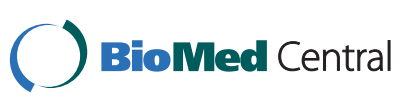

(c) 2015 Engelhardt and Stadler; licensee BioMed Central Ltd. This is an Open Access article distributed under the terms of the Creative Commons Attribution License (http://creativecommons.org/licenses/by/4.0), which permits unrestricted use, distribution, and reproduction in any medium, provided the original work is properly cited. The Creative Commons Public Domain Dedication waiver (http://creativecommons.org/publicdomain/zero/1.0/) applies to the data made available in this article, unless otherwise stated. without a sequenced genome. uaRNAs are a quite new class of non-coding RNAs and have not been extensively analysed yet. We present a catalog of candidates which are excellent targets for experimental verification. Increasing evidence hints to additional regulatory functions of 3'UTRs independent from the processing of the corresponding gene. It is very likely that this mechanism is not only present in humans and mice but also other eukaryotes. Using public data is a great way to get a glimpse of the uaRNAome of the respective species.

doi:10.1186/1471-2105-16-S8-A7

Cite this article as: Engelhardt and Stadler: Evolution of $3^{\prime} \mathrm{UTR}$-associated RNAs. BMC Bioinformatics 2015 16(Suppl 8):A7.

Submit your next manuscript to BioMed Central and take full advantage of:

- Convenient online submission

- Thorough peer review

- No space constraints or color figure charges

- Immediate publication on acceptance

- Inclusion in PubMed, CAS, Scopus and Google Scholar

- Research which is freely available for redistribution Submit your manuscript at
www.biomedcentral.com/submit C BioMed Central
Published: 30 April 2015 